\title{
FAVOURABLE CULTURE CONDITIONS FOR MYCELIAL GROWTH OF HYDNUM REPANDUM, A MEDICINAL MUSHROOM
}

\author{
Aysun Peksen ${ }^{1 *}$, Beyhan Kibar ${ }^{2}$, Gokcen Yakupoglu ${ }^{3}$ \\ ${ }^{1}$ Ondokuz Mayis University, Faculty of Agriculture, Department of Horticulture, 55139 Samsun, \\ Turkey. ${ }^{2}$ Igdir University, Faculty of Agriculture, Department of Horticulture, 76000 Igdir, Turkey \\ ${ }^{3}$ Namik Kemal University, Faculty of Agriculture, Department of Horticulture, Tekirdag, Turkey \\ *E-mail: aysunp@omu.edu.tr
}

\begin{abstract}
In this study, factors such as $\mathrm{pH}$, temperature, carbon and nitrogen sources that affect mycelial growth of Hydnum repandum, a medicinal mushroom, were investigated. Different inoculum media for vegetative inoculum production were also examined. The best suitable $\mathrm{pH}$ for mycelial growth was found to be 5.5. Among constant temperatures, the best mycelial growth was obtained at 20 and $25^{\circ} \mathrm{C}$. The mycelial growth drastically decreased at $15^{\circ} \mathrm{C}$, and no mycelia were obtained at $30^{\circ} \mathrm{C}$. Glucose and mannitol were found to be the most suitable carbon sources. $\mathrm{Ca}\left(\mathrm{NO}_{3}\right)_{2}$ as a nitrogen source gave the best results for mycelial growth. The poorest mycelial growth was noted in sucrose and xylose as carbon sources and in $\mathrm{NH}_{4} \mathrm{NO}_{3}$ and $\left(\mathrm{NH}_{4}\right)_{2} \mathrm{HPO}_{4}$ as nitrogen sources. Peat and peat: vermiculite mixtures $(1: 4,1: 6,1: 8$ and 1:10, v:v) were the best media to use in producing the vegetative inoculum of $H$. repandum
\end{abstract}

Keywords: Hydnum repandum; pH; temperature; carbon; nitrogen; vegetative growth

\section{Introduction}

Hydnum repandum (L. ex Fr.) S.F. Gray is an edible, ectomycorrhizal and medicinal mushroom, which belongs to the class Basidiomycetes, the order Cantharellales and the family Hydnaceae (Phillips, 1994). It is commonly known as the Wood Hedgehog or Hedgehog mushroom. This mushroom is easily recognised because of its spore-bearing structures which are shaped like teeth or spines rather than gills.

H. repandum is an important source of income and also valuable human food for rural population due to its nutritional and medical properties. An extract of the culture mycelia showed $70 \%$ inhibition against Sarcoma 180 solid cancer in mice, while extracts from the fruit bodies showed 90\% inhibition against both Sarcoma 180 and Ehrlich solid cancer in mice (Ohtsuka et al., 1973). Repandiol isolated from $H$. repandum and $H$. repandum var. album displayed potent cytotoxic activity against various tumour cells (Takahashi et al., 1992). $H$. repandum contains $9.16 \%$ crude ash, $27.07 \%$ crude protein, $7.60 \%$ crude cellulose, $3.16 \%$ crude fat, and $53.01 \%$ carbohydrates (Ertan and Gulyavuz, 1993 ). Murcia et al. (2002) stated that $H$. repandum has antioxidant activity. It is also reported that $H$. repandum is an important nutrient for diet (Alonso et al., 2003).

H. repandum is widely distributed in North America and Europe, found single or in groups in summer or fall, and forms ectomycorrhizal association with hardwoods or conifers (Wikipedia, 2012). This mushroom is also naturally and widely present in the macro fungi flora of Turkey. It is widely distributed in the pine, hornbeam, beech and oak forests in Adana, Antalya, Artvin, Balikesir, Bolu, Eskisehir, Giresun, Gumushane, Istanbul, Izmir, Manisa, Ordu, Samsun and Trabzon provinces of Turkey (Solak et al., 2007). It is sold in the local markets and has high export potential (Peksen and Karaca, 2000) because it is a good delicious edible mushroom, having a sweet, nutty taste, mild odour and a crunchy texture.

There is limited information on mycelial growth conditions of $H$. repandum. The fastest mycelium growth was recorded in MEPA and PDA among 8 different media including PDA, ME, BAF, MMN, M40, MEPA, PDYA and MYPA. Mycelium type and form in MEPA and PDA media were radial and radial-floccose, respectively (Kibar and Peksen, 2007). However, the determining of a suitable media requires a detailed investigation to establish the most suitable medium that meets certain basic requirements. To find optimal nutritional and environmental conditions for mycelial growth of H. repandum and to produce its vegetative inoculum are necessary and have a great importance from the point of cultivation of this species. The aim of this study was to determine the best mycelial growth conditions ( $\mathrm{pH}$, temperature, carbon and nitrogen sources) of $H$. repandum, and to realise its vegetative inoculum production.

\section{Materials and Methods}

The study was conducted in the mycelial production laboratory of Department of Horticulture, Faculty of Agriculture, Ondokuz Mayis University between 2008 and 2009.

\section{Collection, identification and isolation}

The fruiting bodies of H. repandum were collected from the pine forests in Sinop province of Turkey in autumn 2008. Identification of mushroom was done using conventional methods (Phillips, 1994). Pure mycelial cultures of $H$. repandum were obtained using tissue culture method as described by Jonathan and Fasidi (2003). The mycelial culture was maintained on Potato Dextrose Agar (PDA) at $25^{\circ} \mathrm{C}$ in complete darkness, and the cultures were stored at $4^{\circ} \mathrm{C}$.

\section{Effect of initial pH and temperature on mycelial growth}

The effect of initial $\mathrm{pH}$ and temperature on mycelial growth of $H$. repandum was investigated on Potato Dextrose Yeast Agar (PDYA) medium. PDYA medium was composed of potato $200 \mathrm{~g}$, dextrose $20 \mathrm{~g}$, yeast extract $2 \mathrm{~g}$, agar $20 \mathrm{~g}$ and $1000 \mathrm{ml}$ of distilled water. pH of PDYA medium was adjusted to 4.0, 4.5, 5.0, 5.5, 6.0 and 6.5 by means of $\mathrm{pH}$ metre with the addition of $1 \mathrm{~N} \mathrm{NaOH}$ or $\mathrm{HCl}$ prior to autoclaving and then 
The media were autoclaved at $121^{\circ} \mathrm{C}$ for 30 minutes. After cooling, PDYA media were poured into the 9 cm diameter Petri dishes. Mycelial agar discs of $5 \mathrm{~mm}$ diameter cut from the margin of an actively growing colony of subcultures were carefully placed in the centre of new Petri plates filled with PDYA. Inoculated Petri plates were sealed with parafilm and placed into separate incubators to incubate at $15,20,25$ and $30^{\circ} \mathrm{C}$ under dark conditions. The experimental design was a completely randomised design with 5 replications.

\section{Effect of carbon and nitrogen sources on mycelial growth}

To screen the effect of different carbon and nitrogen sources on the mycelial growth of $H$. repandum, 7 carbon and 6 nitrogen sources were tested. Glucose, lactose, maltose, dextrose, mannitol, xylose and sucrose were used as carbon sources and each of them was added into PDYA medium at the rate of $20 \mathrm{~g} / \mathrm{l}$. The medium without carbon served as the control (C-free) (Kadiri and Fasidi, 1994). Malt extract, yeast extract, peptone, $(\mathrm{NH} 4)_{2} \mathrm{HPO}_{4}, \mathrm{NH}_{4} \mathrm{NO}_{3}$ and $\mathrm{Ca}\left(\mathrm{NO}_{3}\right)_{2}$ were used as nitrogen sources and each of them was added into PDYA medium at a concentration of $2 \mathrm{~g} / \mathrm{l}$. The control ( $\mathrm{N}$-free) medium was constituted without nitrogen (Daza et al., 2006). Sterilisation and inoculation were carried out as described for the $\mathrm{pH}$ and temperature above. The inoculated plates were incubated at $25^{\circ} \mathrm{C}$ under dark conditions. The experiment was carried out in completely randomised design with 9 replications.

Duration of complete mycelium running, mycelial growth area and colony diameter was measured as mycelial growth parameters in the experiments. Duration of complete mycelium running was determined as the number of days from the mycelium inoculation to time that petri plate was completely covered by mycelium. Mycelial growth area $\left(\mathrm{cm}^{2}\right)$ covered by mycelia was marked when the mycelia growth was completed in any of the Petri dishes, and measured with a digital planimeter. Mycelial colony diameter ( $\mathrm{mm}$ ) was determined by daily measurements in four different point of mycelial colony in the plates with a digital calliper. The average values which were calculated from these measurements were multiplied by two.

\section{Vegetative inoculum preparation}

To produce vegetative inoculum of $H$. repandum, 5 different vegetative inoculum media consisting of peat and peat: vermiculite mixtures $(1: 4,1: 6,1: 8$ and 1:10 v:v) were used. Vegetative inoculum media, in $1000 \mathrm{ml}$ glass culture bottles containing $800 \mathrm{ml}$ of peat or different peat: vermiculite mixtures, were autoclaved at $121^{\circ} \mathrm{C}$ for $1.5 \mathrm{~h}$. After $24 \mathrm{~h}$, vegetative inoculum media was moistened with $200 \mathrm{ml}$ MEPA liquid medium and autoclaved again at $121^{\circ} \mathrm{C}$ for $30 \mathrm{~min}$. After cooling, the culture bottles were inoculated with 4 mycelial discs of $5 \mathrm{~mm}$ diameter. The inoculated bottles were incubated at $20 \pm 2{ }^{\circ} \mathrm{C}$ under dark conditions. The experiment was carried out in completely randomised design with 4 replications. $\mathrm{pH}$ of vegetative inoculum media was determined both after sterilisation and after mycelial growth was completed (Rowell, 1996). Mycelial growth rate $\left(\mathrm{cm} \mathrm{day}^{-1}\right)$ was determined by daily measurements from the two different sections of the culture bottles. Mycelial growth $(\mathrm{cm})$ on the 18 th day was also determined in the trial.

\section{Statistical analysis}

Data obtained from the experiments were subjected to analysis of variance using the SPSS statistical programme, and means showing statistical significance were compared using Duncan's multiple range test.

\section{Results and Discussion}

Means of mycelial growth characteristics obtained from different temperature and $\mathrm{pH}$ applications are presented in Table 1. Statistical analysis of the data on the mycelial growth parameters revealed that significant differences were found among temperatures, $\mathrm{pH}$ and temperature $\times \mathrm{pH}$ interactions with regards to duration of complete mycelium running, mycelial growth area and mycelial colony diameter. The best temperatures for mycelial growth of $\mathrm{H}$. repandum were found to be 20 and $25^{\circ} \mathrm{C}$. The mycelial growth drastically decreased at $15^{\circ} \mathrm{C}(\mathrm{Table} 1)$. It may be sourced from the reducing metabolic activities of the fungus that allow the absorption of essential nutrients needed for growth (Garraway

Table 1: Effect of temperature and initial $\mathrm{pH}$ on the mycelial growth of $H$. repandum on $\mathrm{PDYA}^{1}$

\begin{tabular}{|c|c|c|c|c|c|c|}
\hline \multirow[t]{2}{*}{ Properties } & \multicolumn{4}{|c|}{ Temperature ${ }^{\circ} \mathrm{C}$} & \multirow[b]{2}{*}{$30^{\circ} \mathrm{C}$} & \multirow[b]{2}{*}{ Mean } \\
\hline & $\mathrm{pH}$ & $15^{\circ} \mathrm{C}$ & $20^{\circ} \mathrm{C}$ & $25^{\circ} \mathrm{C}$ & & \\
\hline \multirow{7}{*}{$\begin{array}{l}\text { Duration of } \\
\text { complete mycelium } \\
\text { running } \\
\text { (day) }\end{array}$} & 4.0 & $37.00 a^{*}$ & $19.80 \mathrm{c}-\mathrm{f}$ & $36.40 \mathrm{a}$ & $0.00 \mathrm{~g}$ & $23.30 \mathrm{a} * *$ \\
\hline & 4.5 & $32.40 \mathrm{ab}$ & $20.40 c-f$ & $26.20 \mathrm{bcd}$ & $0.00 \mathrm{~g}$ & $19.75 \mathrm{ab}$ \\
\hline & 5.0 & $22.60 c-f$ & $21.00 c-f$ & $26.80 \mathrm{bc}$ & $0.00 \mathrm{~g}$ & $17.60 \mathrm{abc}$ \\
\hline & 5.5 & $22.80 \mathrm{c}-\mathrm{f}$ & 18.40def & $15.40 \mathrm{f}$ & $0.00 \mathrm{~g}$ & $14.15 \mathrm{c}$ \\
\hline & 6.0 & $33.80 \mathrm{ab}$ & $17.60 \mathrm{ef}$ & $27.00 \mathrm{bc}$ & $0.00 \mathrm{~g}$ & $19.60 \mathrm{ab}$ \\
\hline & 6.5 & $25.00 \mathrm{~b}-\mathrm{e}$ & $19.80 \mathrm{c}-\mathrm{f}$ & $22.80 \mathrm{c}-\mathrm{f}$ & $0.00 \mathrm{~g}$ & $16.90 \mathrm{bc}$ \\
\hline & Mean & $28.93 \mathrm{a}^{* * *}$ & $19.50 \mathrm{~b}$ & $25.77 \mathrm{a}$ & $0.00 \mathrm{c}$ & \\
\hline \multirow{7}{*}{$\begin{array}{l}\text { Mycelial } \\
\text { growth area }\left(\mathrm{cm}^{2}\right)\end{array}$} & 4.0 & $9.86 \mathrm{j} * *$ & $13.601 \mathrm{j}$ & $20.08 \mathrm{f}-1$ & $0.00 \mathrm{k}$ & $10.89 c^{* *}$ \\
\hline & 4.5 & $11.02 \mathrm{j}$ & $23.30 \mathrm{e}-\mathrm{h}$ & $25.02 \mathrm{~d}-\mathrm{g}$ & $0.00 \mathrm{k}$ & $14.84 \mathrm{bc}$ \\
\hline & 5.0 & $17.82 \mathrm{~g}-1$ & $32.74 a-e$ & $27.38 b-f$ & $0.00 \mathrm{k}$ & $19.49 \mathrm{a}$ \\
\hline & 5.5 & $14.441 \mathrm{j}$ & $37.78 \mathrm{ab}$ & $35.98 \mathrm{abc}$ & $0.00 \mathrm{k}$ & $22.05 \mathrm{a}$ \\
\hline & 6.0 & $13.54 \mathrm{ij}$ & $29.52 \mathrm{a}-\mathrm{e}$ & $27.08 \mathrm{c}-\mathrm{f}$ & $0.00 \mathrm{k}$ & $17.54 \mathrm{ab}$ \\
\hline & 6.5 & $16.22 \mathrm{~h}-\mathrm{j}$ & $33.58 \mathrm{a}-\mathrm{d}$ & $38.32 \mathrm{a}$ & $0.00 \mathrm{k}$ & $22.03 \mathrm{a}$ \\
\hline & Mean & $13.82 b^{* *}$ & $28.42 \mathrm{a}$ & $28.98 \mathrm{a}$ & $0.00 \mathrm{c}$ & \\
\hline \multirow{7}{*}{$\begin{array}{l}\text { Mycelial colony } \\
\text { diameter at } 15 \text { th day } \\
(\mathrm{mm})\end{array}$} & 4.0 & $48.55 \mathrm{~h} * *$ & $65.90 \mathrm{ef}$ & $65.37 \mathrm{ef}$ & 0.001 & $44.96 c^{* *}$ \\
\hline & 4.5 & $53.26 \mathrm{gh}$ & $77.85 \mathrm{a}-\mathrm{d}$ & $75.76 \mathrm{bcd}$ & 0.001 & $51.72 b$ \\
\hline & 5.0 & $65.56 \mathrm{ef}$ & $82.34 \mathrm{a}-\mathrm{d}$ & $74.95 \mathrm{cde}$ & 0.001 & $55.71 \mathrm{ab}$ \\
\hline & 5.5 & $61.36 \mathrm{fg}$ & $86.18 \mathrm{ab}$ & $88.21 \mathrm{a}$ & 0.001 & $58.94 \mathrm{a}$ \\
\hline & 6.0 & $59.69 \mathrm{fg}$ & $83.03 \mathrm{a}-\mathrm{d}$ & $74.03 \mathrm{de}$ & 0.001 & $54.19 \mathrm{ab}$ \\
\hline & 6.5 & $65.48 \mathrm{ef}$ & $85.28 \mathrm{abc}$ & $82.96 \mathrm{a}-\mathrm{d}$ & 0.001 & $58.43 \mathrm{a}$ \\
\hline & Mean & $58.98 \mathrm{~b} * *$ & $80.10 \mathrm{a}$ & $76.88 \mathrm{a}$ & $0.00 \mathrm{c}$ & \\
\hline
\end{tabular}




\section{http://dx.doi.org/10.4314/ajtcam.v10i6.4}

${ }^{1}$ Data were arcsine-square root transformed prior to statistical analyses.

*Means followed by different letters are statistically different by Duncan's multiple range test $(\mathrm{P}<0.05)$, **Means followed by different letters are statistically different according to Duncan's multiple range test $(\mathrm{P}<0.01)$.

and Evans, 1984). In the present study, no mycelial growth was observed at $30^{\circ} \mathrm{C}$ (Table 1). Inhibition of mycelium growth at $30^{\circ} \mathrm{C}$ can be attributed to denaturation of important enzymes which catalyse fungal metabolic processes (Jonathan et al., 2004). The findings of this study were in agreement with Kalyoncu et al. (2009) who found that optimal temperatures for six Morchella species were 25 and $20^{\circ} \mathrm{C}$.

The most suitable mycelial growth was obtained at $\mathrm{pH}$ 5.0-6.5, while the mycelial growth at $\mathrm{pH} 4.0$ and 4.5 evidently decreased (Table 1). These results were in agreement with Stanbury et al. (1995) who stated that ectomycorrhizal fungi grow better at mild acidic conditions. Temperature and $\mathrm{pH}$ are accepted to be important environmental factors that control the fungal development (Johansson, 2002). Temperature $\times$ $\mathrm{pH}$ interactions were significant $(\mathrm{P}<0.01)$. The best mycelial growth was determined in pH between 5.0 and 6.5 at 20 and $25^{\circ} \mathrm{C}$ (Table 1$) . \mathrm{Kibar}$ and Peksen (2011a) reported that best mycelial growth was determined in $\mathrm{pH}$ between 4.5 and 6.0 at $25^{\circ} \mathrm{C}$ in both Lactarius pyrogalus and $L$. controversus.

The effect of carbon sources on mycelia growth of H. repandum was significant. Among carbon sources, the best mycelial growth area and mycelial colony diameter were obtained in the media including mannitol and glucose (Table 2). Glucose and mannitol were the most suitable carbon sources for the mycelial growth of A. caesarea (Daza et al., 2006) and L. pyragolus and L. controversus (Kibar and Peksen, 2011a). Guler and Ozkaya (2008) reported that malt extract agar, wheat agar, potato dextrose agar and complete medium yeast extract agar media containing glucose, sucrose, maltose and starch were the best vegetative mycelial growth of Morchella conica.

The lowest mycelial growth area and colony diameter was determined in C-free control medium and media supplemented with sucrose and xylose (Table 2). This result was parallel with the suggestion of Hatakeyama and Ohmasa (2004) who found that the mycelial growth of Suillus and Boletinus was poor in sucrose contained medium.

Table 2: Effect of carbon sources on the mycelial growth of $H$. repandum

\begin{tabular}{cccc}
\hline Carbon sources & $\begin{array}{c}\text { Duration of complete mycelium } \\
\text { running (day) }\end{array}$ & $\begin{array}{c}\text { Mycelial growth } \\
\text { area }\left(\mathrm{cm}^{2}\right)^{1}\end{array}$ & $\begin{array}{c}\text { Mycelial colony } \\
\text { diameter }(\mathrm{mm})^{1}\end{array}$ \\
\hline Xylose & $18.43 \mathrm{c}^{* *}$ & $25.41 \mathrm{de} * *$ & $53.98 \mathrm{~cd} * *$ \\
Lactose & $24.43 \mathrm{~b}$ & $29.07 \mathrm{~d}$ & $59.26 \mathrm{c}$ \\
Sucrose & $33.00 \mathrm{a}$ & $23.10 \mathrm{de}$ & $52.79 \mathrm{~cd}$ \\
Maltose & $17.71 \mathrm{c}$ & $37.03 \mathrm{c}$ & $68.05 \mathrm{~b}$ \\
Mannitol & $15.00 \mathrm{c}$ & $51.80 \mathrm{a}$ & $82.72 \mathrm{a}$ \\
Glucose & $14.86 \mathrm{c}$ & $47.11 \mathrm{ab}$ & $81.65 \mathrm{a}$ \\
Dextrose & $15.71 \mathrm{c}$ & $43.17 \mathrm{bc}$ & $73.15 \mathrm{~b}$ \\
Control (C-free) & $24.14 \mathrm{~b}$ & $19.46 \mathrm{e}$ & $48.87 \mathrm{~d}$ \\
\hline
\end{tabular}

${ }^{1}$ Mycelial growth area and mycelial colony diameter were measured when it was completed in any of Petri plates at the end of the 11 th day after mycelium inoculation for the current study;

**Means followed by different letters in the same columns are statistically different according to Duncan's multiple range test $(\mathrm{P}<0.01)$.

The results of the study carried out to determine nitrogen requirement of $H$. repandum indicated that $\mathrm{Ca}\left(\mathrm{NO}_{3}\right)_{2}$ was the best nitrogen source $(\mathrm{P}<0.01)$. This was followed by peptone. Mycelial growth area and mycelial colony diameter of media containing $\left(\mathrm{NH}_{4}\right)_{2} \mathrm{HPO}_{4}$ and $\mathrm{NH}_{4} \mathrm{NO}_{3}$ were lower than that of the control and the other nitrogen sources (Table 3). It is generally asserted that ammonium is the most commonly used nitrogen source for most ECM fungi (Rangel-Castro et al., 2002; Sangtiean and Schmidt, 2002; Daza et al., 2006), but the results from the present study were contrary to the reports of these researchers.

Table 3: Effect of nitrogen sources on the mycelial growth of H. repandum

\begin{tabular}{cccc}
\hline Nitrogen sources & $\begin{array}{c}\text { Duration of complete mycelium } \\
\text { running (day) }\end{array}$ & $\begin{array}{c}\text { Mycelial growth } \\
\text { area }\left(\mathrm{cm}^{2}\right)^{1}\end{array}$ & $\begin{array}{c}\text { Mycelial colony } \\
\text { diameter }(\mathrm{mm})^{1}\end{array}$ \\
\hline$\left(\mathrm{NH}_{4}\right)_{2} \mathrm{HPO}_{4}$ & $17.29 \mathrm{ab} * *$ & $30.10 \mathrm{~d}^{* *}$ & $56.63 \mathrm{~d}^{* *}$ \\
$\mathrm{NH}_{4} \mathrm{NO}_{3}$ & $19.86 \mathrm{a}$ & $36.11 \mathrm{~cd}$ & $66.47 \mathrm{~cd}$ \\
$\mathrm{Peptone}$ & $14.14 \mathrm{bc}$ & $51.16 \mathrm{ab}$ & $80.27 \mathrm{ab}$ \\
$\mathrm{Ca}\left(\mathrm{NO}_{3}\right)_{2}$ & $11.00 \mathrm{c}$ & $56.86 \mathrm{a}$ & $86.20 \mathrm{a}$ \\
Malt extract & $15.29 \mathrm{bc}$ & $42.60 \mathrm{bc}$ & $72.59 \mathrm{bc}$ \\
Yeast extract & $14.86 \mathrm{bc}$ & $41.09 \mathrm{bc}$ & $69.66 \mathrm{bc}$ \\
Control (N-free) & $16.29 \mathrm{ab}$ & $41.43 \mathrm{bc}$ & $72.69 \mathrm{bc}$ \\
\hline
\end{tabular}

${ }^{\mathrm{T}}$ Mycelial growth area and mycelial colony diameter were measured when it was completed in any of Petri plates at the end of the 11 th day after mycelium inoculation for the current study;

**Means followed by different letters in the same columns are statistically different according to Duncan's multiple range test $(\mathrm{P}<0.01)$.

Initial $\mathrm{pH}$ values of the vegetative inoculum media ranged from 5.47 to $7.30 \mathrm{pH}$ of media at the end of mycelial growth was found between 6.08 and 7.22. In vegetative inoculum media studies, the effects of vegetative inoculum media on mycelial growth were found nonsignificant (Table 4). The best mycelial growth for T. terreum was obtained from peat:vermiculite mixtures in the rate of 1:4 and 1:6 (Kibar and Peksen, 2011b). In another study, peat: vermiculite mixture in the rate of 1:4 was found to be the most suitable vegetative inoculum medium for L. pyrogalus (Kibar and Peksen, 2011a). In many studies, it was reported that the most appropriate media to obtain the vegetative inoculum of ectomycorrhizal mushrooms were peat, vermiculite, sphagnum moss and perlite mixtures moistened with different liquid nutrient media (Santiago-Martínez et al., 2003; Parlade et al., 2004; Flores et al., 2005).

Table 4: $\mathrm{pH}$ values of the vegetative inoculum media and their effects on the mycelial growth of $H$. repandum

\begin{tabular}{ccccc}
\hline Media & $\begin{array}{c}\text { Initial pH } \\
\text { of media }\end{array}$ & $\begin{array}{c}\mathrm{pH} \text { of media at the end of mycelial } \\
\text { growth }\end{array}$ & $\begin{array}{c}\text { Mycelial growth rate } \\
\left.(\mathrm{cm} \mathrm{day})^{-1}\right)\end{array}$ & $\begin{array}{c}\text { Mycelial growth }(\mathrm{cm})(18 \text { th } \\
\text { day) }\end{array}$ \\
\hline Peat & $5.47^{\text {ns }}$ & $6.08^{\text {ns }}$ & $1.08^{\text {ns }}$ & $14.18^{\text {ns }}$ \\
Peat:vermiculite $(1: 4)$ & 6.88 & 7.01 & 1.07 & 13.73 \\
Peat:vermiculite (1:6) & 7.10 & 7.22 & 1.06 & 13.03 \\
Peat:vermiculite (1:8) & 7.24 & 7.10 & 1.14 & 13.64 \\
Peat:vermiculite (1:10) & 7.30 & 7.20 & 0.94 & 13.31 \\
\hline
\end{tabular}




\section{http://dx.doi.org/10.4314/ajtcam.v10i6.4}

ns: non-significant

In conclusion, the most suitable mycelial growth of $H$. repandum was obtained at 20 and $25^{\circ} \mathrm{C}, \mathrm{pH} 5.5$, by using glucose and mannitol as carbon sources and $\mathrm{Ca}\left(\mathrm{NO}_{3}\right)_{2}$ as nitrogen source. The poorest mycelial growth was recorded in sucrose and xylose as carbon sources and $\mathrm{NH}_{4} \mathrm{NO}_{3}$ and $\left(\mathrm{NH}_{4}\right)_{2} \mathrm{HPO}_{4}$ as nitrogen sources. It can also be concluded that the vegetative inoculum of $H$. repandum can be produced by cultivating the fungus in media which are prepared by peat and peat:vermiculite mixtures. To know the most suitable nutritional and environmental conditions for mycelial growth of H. repandum and to produce its vegetative inoculum would be useful for successful cultivation of this mushroom.

\section{Acknowledgment}

The authors are grateful to the Unit of Scientific Research Projects (Z-497) of Ondokuz Mayis University for financial support.

\section{References}

1. Alonso, J., Garcia, M. A., Perez-Lopez, M. and Melgar, M. J. (2003). The Concentrations and Bioconcentration Factors of Copper and Zinc in Edible Mushrooms. Arch. Environ. Contain. Toxicol., 44(2): 180-188.

2. Wikipedia the Free Encyclopedia (2012). http://en.wikipedia.org/wiki/Hydnum_repandum. Accessed date: 25.06.2012.

3. Daza, A., Manjon, J. L., Camacho, M., Romero de la Osa, L., Aguilar, A. and Santamaria, C. (2006). Effect of Carbon and Nitrogen Sources, $\mathrm{pH}$ and Temperature on in Vitro Culture of Several Isolates of Amanita caesarea (Scop.:Fr.) Pers. Mycorrhiza, 16(2): 133-136.

4. Ertan, Ö. O. and Gulyavuz, H. (1993). Determination of the Nutritional Properties of Hydnum repandum (L.ex Fr.) S.F. Gray. Turk. J. Agric. For., 17: 323-329.

5. Flores, R., Diaz, G. and Honrubia, M. (2005). Mycorrhizal Synthesis of Lactarius indigo (Schw.) Fr. with Five Neotropical Pine Species. Mycorrhiza, 15: 563-570.

6. Garraway, O. M. and Evans, C. R. (1984). Fungal Nutrition and Physiology. Singapore: John Wiley. New York, Toronto.

7. Guler, P. and Özkaya, E. G. (2008). Sclerotial Structures of Morchella conica in Agar Media with Different Carbohydrates. Acta Alimentaria, 37(3): 347-357.

8. Hatakeyama, T. and Ohmasa, M. (2004). Mycelial Growth of Strains of The Genera Suillus and Boletinus in Media with A Wide Range of Concentrations of Carbon and Nitrogen Sources. Mycoscience, 45: 169-176.

9. Johansson, J. F. (2002). Belowground Ectomycorrhizal Community Structure Along a Local Nutrient Gradient in a Boreal Forest in Northern Sweden. Swedish University of Africultural Sciences, Examensarbete, $20 \mathrm{p}$.

10. Jonathan, S. G. and Fasidi, I. O. (2003). Requirements for Vegetative Growth of Tricholoma lobayensis (Heim), a Nigerian Edible Fungus. Adv. Food Sci., 25(3): 91-95.

11. Jonathan, S. G., Fasidi, I. O. and Ajayi, E. J. (2004). Physico-Chemical Studies on Volvariella esculenta (Mass) Singer, a Nigerian Edible Fungus. Food Chem., 85: 339-342.

12. Kadiri, M. and Fasidi, I. O. (1994). Growth Requirements of Lentinus subnudus Berk, a Nigerian Edible Mushroom. Chem. Mikrobiol. Technol. Lebensm., 16(314): 80-84.

13. Kalyoncu, F., Oskay, M. and Kalyoncu, M. (2009). The Effects of Some Environmental Parameters on Mycelial Growth of Six Morchella Species. JPAM, 3(2): 467-472.

14. Kibar, B. and Peksen, A. (2007). The Effect of The Different Nutrient Media on The Mycelium Growth of Hydnum repandum Mushroom Species. Proceedings of the Turkey V National Horticulture Congress, Sept. 4-7 Erzurum, 201-205.

15. Kibar, B. and Peksen, A. (2011a). Mycelial Growth Requirements of Lactarius pyrogalus and Lactarius controversus. Afr. J. Microbiol. Res., 5(28): 5107-5114.

16. Kibar, B. and Peksen, A. (2011b). Nutritional and Environmental Requirements for Vegetative Growth of Edible Ectomycorrhizal Mushroom Tricholoma terreum. Zemdirbyste-Agriculture, 98(4): 409-414.

17. Murcia, M. A., Martínez-Tomé, M., Jiménez, A.M., Vera, A.M., Honrubia, M. and Parras, P. (2002). Antioxidant Activity of Edible Fungi (Truffles and Mushrooms): Losses During Industrial Processing. J. Food Protec., 65(10): 1614-1622.

18. Ohtsuka, S., Ueno, S., Yoshikumi, C., Hirose, F., Ohmura, Y., Wada, T., Fujii, T., and Takahashi, E. (1973) Polysaccharides having an anticarcinogenic effect and a method of producing them from species of Basidiomycetes.UK Patent No 1331513.

19. Parlade, J., Pera, J. and Luque, J. (2004). Evaluation of Mycelial Inocula of Edible Lactarius Species for The Production of Pinus pinaster and P. sylvestris Mycorrhizal Seedlings Under Greenhouse Conditions. Mycorrhiza, 14(3): 171-176.

20. Peksen, A. and Karaca, G.H. (2000). Edible Mushroom Species Found in Samsun Province and Their Consumption Potentials. Proceedings of the 6th Turkey Edible Mushrooms Congress, Sept. 20-22, 2000, Bergama, Izmir, pp. 100-111.

21. Phillips, R. (1994). Mushrooms and Other Fungi of Great Britain and Europe. Milan, Italy, p. 288.

22. Rangel-Castro, J. I., Danell, E. and Taylor, A. F. S. (2002). Use of Different Nitrogen Sources by the Edible Ectomycorrhizal Mushroom Cantharellus cibarius. Mycorrhiza, 12: 131-137.

23. Rowell, D. L. (1996). Soil Science Methods and Applications. Wesley Longman Limited, Harlow.

24. Sangtiean, T. and Schmidt, S. (2002). Growth of Subtropical ECM Fungi with Different Nitrogen Sources Using a New Floating Culture Technique. Mycol. Res., 106(1): 74-85.

25. Santiago-Martinez, G. Estrada-Torres, A., Varela, L. and Herrera, T. (2003). Growth on Seven Nutritive Media and in Vitro Synthesis of One Strain of Laccaria bicolor. Agrociencia, 37(6): 575-584.

26. Solak, M. H., Isıloglu, M., Kalmıs, E. and All1, H. (2007). Macrofungi of Turkey: Checklist, Bornova-Izmir.

27. Stanbury, P. F., Whitaker, A. and Hall, S. (1995). Principles of Fermentation Technology. Butterworth Heinemann, Oxford, UK. p. 357.

28. Takahashi, A., Endo, T. and Nozoe, S. (1992). Repandiol, a New Cytotoxic Diepoxide from the Mushrooms Hydnum repandum and H. repandum var. album. Chem. Pharmaceut. Bull., 40(12): 3181-3184. 